\title{
Te leer in de eerstelijn
}

Citation for published version (APA):

Crebolder, H. F. J. M. (1987). Te leer in de eerstelijn. Rijksuniversiteit Limburg. https://doi.org/10.26481/spe.19870911hc

Document status and date:

Published: 11/09/1987

DOI:

10.26481/spe.19870911hc

Document Version:

Publisher's PDF, also known as Version of record

\section{Please check the document version of this publication:}

- A submitted manuscript is the version of the article upon submission and before peer-review. There can be important differences between the submitted version and the official published version of record.

People interested in the research are advised to contact the author for the final version of the publication, or visit the DOI to the publisher's website.

- The final author version and the galley proof are versions of the publication after peer review.

- The final published version features the final layout of the paper including the volume, issue and page numbers.

Link to publication

\footnotetext{
General rights rights.

- You may freely distribute the URL identifying the publication in the public portal. please follow below link for the End User Agreement:

www.umlib.nl/taverne-license

Take down policy

If you believe that this document breaches copyright please contact us at:

repository@maastrichtuniversity.nl

providing details and we will investigate your claim.
}

Copyright and moral rights for the publications made accessible in the public portal are retained by the authors and/or other copyright owners and it is a condition of accessing publications that users recognise and abide by the legal requirements associated with these

- Users may download and print one copy of any publication from the public portal for the purpose of private study or research.

- You may not further distribute the material or use it for any profit-making activity or commercial gain

If the publication is distributed under the terms of Article $25 \mathrm{fa}$ of the Dutch Copyright Act, indicated by the "Taverne" license above, 


\section{te leer in de eerstelijn}

rede

Litgesproken bij de aanvaarding van het ambt wan hoogleraar ter coördinatie van het onderwijs in de eerstelijns gezondheidszorg op wrijdag 11 september 1987 door

Dr.H.F.J.M.Crebolder

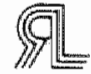



Zeer gewaardeer de toehoorders,

De benoeming van een huisarts tot hoogleraar voor courdinatie van het onderwijs in de eerstelijn, duidt op het belang dat deze faculteit hecht aan de eerstelijin, aan het onderwijs in de eersteliin en aan de plaats en functie van de huisartsgeneeskunde daarbij.

In deze openbare les wil ik het concept "eerstelijin" en de verhouding tot de gezondheidszorg nader beschowwen, ingaan op de relatis tussen faculteit en regio en enige onderwijskundige consequenties overwegen.

Ervaringen ontleend aan mijn werkzaamheden in het gezondheidscentrum withuis te Venlo geven een coulleur locale aan de gepresenteerde inzichten en opvattingen. Mijn geboortegrond, de huisartsgeneeskunde, zal die inkleuring onontkoombaar mee bepalen.

\section{EERSTELI JN}

Het nogal militairistische begrip "eerstelijn" of "eerste echelon" is in 1974 door de befaamde nota Hendriks geintroduceerd (1). De denkbeelden over echelonnering van de gezondheidszorg zijn wetenschappelijk verwoord door Querido, die ze in 1962 tijdens een zitting van de Wereld Gezondheidsorganisatie (WHO) naar voren bracht (2).

Met eerstelijn wordt bedoeld, de professionele zorg die dichtbij huis ligt en voor iedereen rechtstreeks toegankelijk is. Daarin vinden we kerndisciplines voor welke de nadruk op zorg ligt, zoals algemeen maatschappelijk werk en gezinszorg, en disciplines voor welke het accent op gezondheidszorg ligt, zoals wijkverpleging en huisartsgeneeskunde. De apotheker, verloskundige, tandarts en fysiotherapeut vinden er eveneens hun werkveld. Eerstelijns geneeskunde is in feite een 
symoniem voor huisartsgeneesunde.

Bi de overgang van gezondheid naar ziekte, dan wel bij twijel of er sprake is wan ziekte, wenden mensen zich tot het eerste echelon. Is de ziekte of de twijfel ernstig genoeg, dan trekt men van het eerste naar het tweede echelon, waar zich specialiaten en geavanceerde voorzieningen bevinden. En everzeer is er een weg terug na geheel of gedeeltelijk herstel, of als or medsch-technisch geen genezing meer is te verwachten.

In de beweegredenen om de eerstelijn als zodanig te kerschetsen en de functie ervan te versterken. zijn vanaf het begin twee tendenzen te onderscheiden (1). De ene is woornamelijk ideologisch van aard, betrekking hebbend op matgchappelijke normen en warden. De meest wezenlijke darvan is wel de autonomie van de eigen leefwereld wan de patients die zich ondermeer uit in inspraak en participatie. En heel concreet vertaald kan dat zijn: de wens om thuis te bevallen en thuis te sterven.

De andere is wooral ecomomisch van aard, betrekking hebbend op doelmatigheid em ordening. Concreet betekent dat bijuorbeeld, een zodanige afstemming wan de functies van de eerste- en tweedelijin, dat er geen onnodige verwijzingen platwinden.

Meestal worden beiden tendenzen tegelijkertijd: als vanzelfsprekend samenhangend" gepresenteerd. Door de batifnt zoveel mogelijk in en door de eerstelijn op te vangen. wordt hij en dicht bij huis en goedkoop behandeld. Dicht bij huis betekent: thuis of in een voorziening daer $v 1$ akbij. Goedkoop wil zeggen en nu citeer ik het rapport van de commissie Dekker: "een terecht niet verwezen patiunt ontvangt goede zorg tegen de ladgste $\operatorname{prijs} s^{i t}(3)$. 


\section{PRIMARY HEALTH CARE}

In deze ontwikkeling past het "primary health care" (PHC) concept van de WHO.

Eerstelijns gezondheidszorg is wel een letterijike vertaling van primary health care, maar het WHO-concept gaat verder. Essentieel er in is de verbreding wan "medische zorg" naar "gezondheidszorg" (4).

De principes van de PHC zijn de volgende:

- de gezontheidszorg dient te zijn gerelateerd an de noden van de bevolking, voor iedereen toegankel ijk en acceptabel:

- participatie van de bevolking, individueel en collectief, is essentieel:

- PHC moet effectief en efficiunt zijin: en

- PHC moet een onderdeel vormen van een landelijke samenhangende gezondheidszorg.

De eerste twee principes zijn van ideologische, de latste twee van economische aard.

Primary health care wordt in 1978 de speerpunt van het WHO-beleid en windt $z$ in Dolitieke beslag in de zogenaamde verklaring van Alma Ata (5).

Hoewel het gaat om een mondiale verklaring, makt deze de indruk wooral bedoeld te zijn voor ontwikkelingslanden. Daar immers is de relatie tussen gezondheid en sociaal-economische factoren heel direkt en duidelijk. De wicieuze cirkel: armoede, onwetendheid en ziekte, is het kenmerk van die landen. Maar ook hier, in het rijke westen bestat die relatie tussen gezondheid en $90-$ cial-economische factoren al is de levensverwachting veel beter. Denk maar an gezondheid bedreigende leefstijlen, die bijdragen an de bekende doodsoorzaken: maligniteiten, atherosclerose, verkeersongevall then nu ook AIDS. Bovendien blijken ook hier ziekte en te uroege sterfte oververtegenwoordigd te zijn bij de lagere sociale lagen (6). En denk aan de milieuverontreiniging, wartoe ik niet alleen Tsjermobyl en zure regen reken, maar ook lawail het dicht op elkat 
wonen, geweld oo strat, op voetbalveld en op TV. De paradox is dat dit primary health care model, met enig cucces wordt toegepast in rijke landens terwijl het in ontwikkelingslanden veel moeizamer vorm en inhoud krijgt. Naast gebrek aan geld* mankracht en infraatructure, is ook valk de politieke wil afwezigan op nationale achaal een PHC-systeem op te bouwen. De aantrekkingskracht van een omvangrijk en goed geoutilleerd ziekenhuis, is nog steeds groter dan een reeks eenvoudig ogende curatieve voorzieningen, die een geintegreerd geheel vormen met activiteiten gericht op zorg, prewentie en voorlichting.

Zo heb ik in Tanzania in de jaren zeventig van dichtbij de bouw van een groot en prestigieus ziekenhuis meegemakt. Het functioneert slecht en is razend duur. In plaats daarvan hadden gemakkelijk honderd gezondheidscentra gebouw en onderhouden kunnen worden.

Maar ook in rijke landen is de praktijk van PHC moeilijk, zelis bijhet minder omvattende concept "eerstelijn".

Deze faculteit is darvan het levende bewijs. Het is om een complex van redenen - niet gelukt om de voorzieningen in deze regio op een zodanige wijze te bundelen - te integreren - dat enerzijds een op traditionele leest geschoeid academisch ziekenhuis overbodig zou blijken en dat anderzijds de eersteljin valdoende functioneel zou aansluiten op de tweede $(7,8)$.

Het lijkt erop dat de eerstelijn pas een echte kans krijgt als er een (over)verzadiging is bereikt aan ziekenhuisvoorzieningen.

Daaraan ligt mijns inziens een diepe psychologische drijfueer ten grondslag. De wetenschap dat er in de onmiddellijke nabijheid een adequate voarziening is om Is levensbedreigend ervaren situaties op te vangen. geeft voldoende geestelijke rust aan ons allen om ten volle te kunnen profiteren van de potenties van het eerste echelon. Onderzoek gedalan rondom de vestiging van een nieuw ziekenhuis in Lelystad. waar voordien geen ziekenhuis bestond, ondersteunt die bewering. Voor 
de komst van het ziekenhuis werd de inwoners gevraagd in hoverre $z i j$ het wervellend wonden dat er geen ziekenhuis was. "Slechts 4 procent vond het niet verweliend, maar liefst 64 procent vond het zeer vervelend. Als belangrijkste reden hiervoor werd opgegeven dat men in noodgevallen niet op tijd in het ziekenhuis zou zijn en dat het vervelend is ver wan je woonplats in het ziekenhuis te liggen". (9).

Bensing houdt in haar artikel "Wie wil in Nederland Primary Health Care" de beide ideologische en beide economische orincipes tegen het licht wan de Nederlandse situatie (9). Het $z i j n$ volgens haar twee stromingen, die elkaar toevallig - door hun gelijktijdigheid - hebben gevonden en vervolgens een hecht en stabiel bondgenootschap hebben gesloten. Zonder elkar zouden ze niet in stat zijn geweest zulk een krachtige beweging te mobiliseren.

Maar op het uitvoeringsniveau, het niveau van de concrete matregelen, $z i j n$ de twee stromingen valk verwarrend en tegenstrijdig.

\section{SAMENWERK ING}

Hoe staat het nu, 13 jaar na de nota-Hendriks, met die beide tendenzen om de eerstelijing gezondheidszorg te bevorderen?

De eenvoudige veronderstelling dat door het op cen 1 i in platsen, echelonneren, wan medische en niet-medische disciplines, die global gesproken dezelf de functionele kenmerken en gerichtheid vertomen" de zorgverlening en beter en goedkoper zou worden. kon niet rechtatreaks worden a angetoond. De samenwerking van werkers van zulke diverse pluimage, al husartsen. wijkverpleegkundigen en matschappelijk werkers, bleek aanleiding te geven tot grote en, achteraf woorspelbare obstakels. Hen sprak elkaars taal niet of nauwelijks. Aan toch gemeenschappelijke begrippen als zorg, bereikbarheid en beschikbaarheid, werden heell verschillende inter- 
pretatues gegeven, samenhangend met een weelvoud van verschillen in achtergrond, optiek wan werken en doelgroepen. Daarenboven zijn de verschillen in opleidingsniveau, sociale status en het vrije ondernemerschap versus dienstuerbiand bronnen wan potentile disharmonie $(10)$.

De huibarts stat in principe open voor iedere hulpvraag. De wijkverpleegkundige heeft ook een breed hulp-aanbod, doch richt zijn aandacht vooral op zeer jeugdigen en op chronisch zieken en bejaarden. Hij heeft althans in theorie een meer op deel-populaties gerichte, meer preventieve en voorlichtende werkwijze. De matschapdelijk werker $z$ iet maar een klein segment van de populatio, met een specifieke materiete en immateriele problematiek en voor een groot deel na verwijzing. De taak vain de gezinsverzorger is "het op zeer concrete wije handhaven van een min of meer stabiele Dsychosociale thuissituatie ondanks ziekte handicap of andere uitvalverschijnselen en werken aan herstel van het eigen vermogen wam de clibut om thuis verder te kunnen leven" (11).

Hoewel de extramurale tysiotherapie niet behoort tot het officitle kernkwatet, en de patient zich niet rechtstreeks tot hem kan wenden, behoort ook deze discipline dartoe te worden gerekend (12). En ook de huidige doktersassistente zal zich meer en meer professionaliseren tot centrum- of team-assistente.

Zij - in de toekomst ook hij - zal ook eigen taken gaan verwullen, met name in de sfeer van monitoring en preventie (13).

De lllusie van de beginjaren zeventig; als zou er een interdisciplinair hulpuerleningsmocel bestaan of zi in te ontwerpen, is geleidelijk aan verlaten (14). De medewerking wan de overheid en de koepelorganisaties der kerndisciplines. was te sparzam om een grote sprong voorwart te maken. De economische steun was te gering en te arzelend. Te snel werden substitutieeffecten verwacht met betrekking tot de tweedelijn. Die worden nu pas zichtbar en dan vooral in gezondheids- 
centra (15). Dat ist erop dat een verbeterde organisatiegraad op meso-niveau gunstige financicel-economische gevolgen heeft. Echter, het tempo van de modernisering wan de eerstelijn als geheel is nog te traag on te kunnen concurreren met de goed georganiseerde tweedeli jn.

\section{HET SOCIALE EN MEDISCHE HULPUERLENINGSMODEL}

Maar ook op het ideologisch niveau is een belangrijke oorzaak aan te wijzen. Deze is gelegen in het onvermogen het sociale en medische hulpverleningsmodel op een bevredigende wijze met elkaar te verbinden en zo een werkelijk integrale benadering te realiseren.

Het medisch model houdt in het trachten wast te stellen van een 'ziekte' met oorzak, verschijnselen, verloop en diagnose voerend tot een therapeutische of preventieve actie. Het sociale model biedt een referentiakader, warbij centraal stat dat de mens een sociaal gevormd of vervormd wezen is, levend in, deelhebbend aan en de invloeden ondergaand van matschappelijke structuren en processen. Natuurlijk is het zo, dat de medicus practicus en dan met name de hulsarts voortdurend rekening houdt met en oog en oor heeft voor psychische en sociale determinanten bij ziekte en ziektegedrag. Evenzeer zal de matschappellijk werker zonodig medische informatie bij zijn beleid betrekkem. En vanzelfsprekend zal de wijkverpleegkundige de krachten wan de patient en de directe omgeving mobiliseren. om owername, aanvuliing of herstel van de zelfzorg te beworderen. Maar van een echte gezamenlijkheid $c . a$. integratie kan nauwelijks sprake zijn, omdat de vertrekpunten te verschillend zijn.

A) in 1972 kondigde Lamberts, op grond van de ervaringen in het gezondheidscentrum ammoord; de op de werkvloer war te nemen caesuur aan tussen het sociale en medische model (16). De huisarts is zich sindsdien meer gaan concentreren op de medisch- ambachtelijke 
aspecten wan zijn beroep. Een vanzelfaprekende samenwerking vari de huisartg is derhalve t verwachten met de ijkverpleging en de fysiatherapie. Hun land van herkofist is identiek. Het medisch model is in. het sociale model is uit. En interdigciplinaire samenwerking betekent in de praktijk: weet hebben van elkaars kennen en kunnen en in stat zijn daarvan op een edewate wijze gebruik te maken. De gemeenschappelijk basis is het gegeven, dat de hulp en de zorg am "thuis" zijn gecentreerd: thuiszorg (17).

De pogingen om die medisch-sociale of social-medische hybride tot leven te brengen, zijn ijns inziens een niet geringe rem geweest voor de groei van samenwerkingsverbanden in de eerstelijn. In essentie is deze problematick terug te voeren op het al beschreven en ingebakken conflict tussen ideologische en economische doeleinden. Philipsen bezigt in dit verband de termen substantiele en functionelle rationaliteit (18).

21 in gedachtengang - ten dele ontleend aan anderen kan leiden tot een uitweg uit de huidige conceptuelle impasse. Substanticle rationaliteit staat voor begrippen als zingeving, beleving, communicatie en eigen leefwereld. Deze berust op het vermogen de werkelijkheid te ervaren als een geordend, geintegreerd geheel.

Bij functionele rationaliteit gat het om instrumentelle systemen. die succesvolle en meetbare procedures en protocollen opleveren, en die leiden tot differentiatie en specialisatie. De substantiele rationaliteit lijkt steeds meer in de verdrukking te komen, wordt als het ware "gekoloniseerd" door de functionele rationaliteit. In de gezondheidszorg uit zich dit op een aantal terreinen:

- Dverheersing van cure boven care. Diagnose en therapie, behandeling en genezingl zijn gemakkelijker op hun succes te beoordelen dan verzorging, verpleging en ondersteuning.

Er is een sterk benadrukking gekomen van het methodisch handelen. Processen worden tot procedures: de arts streeft protocollaire geneeskunde 
na en de verpleegkundige formuleert een verpleegplan.

- De geneeskunde wordt woornamelijk gevoed door biomedische kernil.

- Somatische interpretaties van ziekte en gezondheid nemen sterk in betekenis toe, los van meer osychologische en sociale.

De succesvolle differentiatie van de zorg, leidt tot gefragmenteerde behandeling en verzorging.

\section{VOORBEELDEN}

Ik geef u twee voorbeelden, warmee ik zelf ervaring heb opgedaan. De hierboven genoemde terreinen. zijh daarin terug te vinden. De voorbeelden geven ook aan op welke wijze een evenwicht is te vinden tussen beide rationaliteiten.

Het earste betreft de jeugdgezondheidszorg.

Wat is hier meer voor de hand liggend, dan dat de eigen huisarts en de eigen wijkverpleegkundige, de jonge gezinnen met kinderen tussen 0 en 4 jaar tezamen begeleiden (19). Tezamen hebben zij een goed beeld wan het functioneren van het gezin. De huisarts is op de hoogte van de gezondheidsstoornissen die aanleiding gaven tot een hulpuraag tijdens het gewone spreekuur. De hulpuragen in die leeftijdscategorie vormen immers de top wan alle gepresenteerde morbiditeit. 0ok heeft hij veelal een beeld wan de leefwereld, wan het relatieotroon* van de manier warop ouders en kindferenj met elkaar omgaan. De wijkverpleegkundige completeert dat beeld door zijn kennis van het sociale netwerk, dat is verkregen door observaties tijdens huisbezoeken (20).

Toch kost het moeite het consultatiebureau voor de eersteli in te behouden (21). In de jaren voor en direkt na de tweede wereldoor log, was het bestaansrecht van deze consultatiebureau's buiten kjjf. Ermstige infectiezlekten. voedingsstoornissen en avitaminosen kwamen toen veelvuldig voor. Daarvan is urijwel geen sprake meers 
tenzij men vetzucht als een voedingsstoornis aanmerkt. Nu gat het weeleer om het volgen van de psychomatore ontwlkeling en het geven van adviezen op het gebied van voeding en opvoeding (22). Eerstellijns teams moeten daartoe, zeker na de nodige bijscholing in stat worden geacht.

Een dergelijke samenwerking wan huisarts en wijkverpleegkundige, het samen bezig zijn met dezelfde populatie, zal een a anzet, een opstap kunnen vormen voor het witwerken wan een eerstelijns interdisciplinair hulpverleningsconcept. Bouwstenen daarvoor zijn: de samenturing tussen preventie en gepresenteerde morbiditeit, de gezinsmatige benadering en de betekenis van het sociale netwerk.

Deze vorm van samenwerken kan worden uitgebreid tat de gezamenlijke zorg voor bejaarden. Een of andere vorm wan monitoring van bejaarden en zeker de hoogbejaarden in de thuissituatie zai nodig en nuttig zijn. In een Deens experiment leidde deze werkwijze tot een significante daling wan mortalitejt en ziekenhuisopnamen. Bovendien bleken de kosten van de gezandheidszorg gehalveerd (23).

Het tweede voorbeeld gat over diabetes mellitus type II.

Bij de begeleiding van diabeten stat central het voorkbmen van complicaties en invaliditeit. Het succes van de behandeling hangt in bellangrijke mate af wan de trouw wan de patient aan de geadviseerde therapie. De consensus groeit, dat deze chronische ziekte die bij 2 procent wan de bevolking en bij minstens 6 procent van de 60-plussers voorkomt, in de eerstelijn behandeld en begeleid kan en moet worden (24). De argumenten daarvoor ijn tenminste tweerlei. Voorlichting en in die voorlichting aansluiten bij de belevingswereld en leefwereld van de patient, is even essentieel als het vastleggen van biochemische parameters en bevindingen bij lichamelijk onderzoek (25). En de kwaliteiten van het gezin, zoals de grootte en de onderlinge relaties. 
lijken samen te hangen met de mate van geconstateerde trouw aan het voorgestelde beleid (26).

Een soortgelijke argumentatie is ook wallide voor andere categorieun, zoals patiunten die een wasculair accident hebben doorgemakkt, CARA-patienten, patidnten met een rheumatoide arthritis en patiwnten na een operatie wegens een mammacarcinoom of colon-carcinoom zonder metastasen. De totale prevalentie van deze chronische aandoeningen bedraagt ongeveer 70 per 1000 (27). Het allergrootste deel van hen is nu nog in zorg bij de specialistische geneeskunde, terwijl er op vak-technische gronden onvoldoende redenen zijn de begeleiding van hen niet aan de eerstelijn toe te vertrowwen. En met eerstelijn bedoel ik werkelijk alle disciplines. Onderwijskundig is het van groot belang, dat de studenten leren en ervaren hoe deze problematiek in de eerstelijn kan worden aangepakt. Voor hun beeldvorming ten aanzien van de witoefening der geneeskunde is dat bepalend.

\section{EERSTELIJNS GENEESKUNDE EN FACULTEIT}

De huisarts wordt gezien als de kernfiguur in het eerste echelon. Hij vertaalt als het ware de ongedifferentieerde uraag naar gezondheidszorg en handelt die in 80-90 procent der gevallen zelf af. Hij onderhoudt de verbindingen met de andere specialisten in de tweedelijn en de andere hulpverleners in de eerstelijn. Hij zit in het kruispunt van het geneeskundig en het sociale hulpverleningssystem (28).

In de korte tijd dat ik werkzamben in deze instelling, is het mij opgevallen dat het vakgebied "eerstelijns geneeskunde" weinig wetenschappelijke warardering ondervindt. Dat is opmerkeijk. Want al in 1972 , toen de basisfillosofie van deze de achtste medische faculteit werd geconcipieerd, stat geschreven: "Speciale aandacht en onderzoek moet worden besteed a an de opleiding van artsen voor het eerste echelon" en "team- 
vorming van de arts met niet-medische deskundigen: de ontwikkeling van groepspraktijken en de bouw van speciale gezondheidgcentra liggen hierbij in de verwachting" $17 \mathrm{y}$.

Vanwar die geringe wardering? Zijn de "eerstelijners" - voor de faculteit der geneeskunde zijn dat de huisartsen - minder intelligent dan de tweedelijners? Werken ze niet hard genoeg?

Zulke psychologismen helpen ons niet verder. Het ontbreekt immers niet aan inteliigentie en werklust. Integendeel. Er is en wordt bijzonder hard en met veel creatiwiteit gewerkt in de eerstelijn. Jas soms gehold naar de horizon (29).

Uit de beschouwing van de WHO-principes moge blijken dat de materie weerbarstig is. De opleiding kan niet anders dan onvoldoende zijn en de plats wan de eerstelijn in het geheel van de zorg brengt heel eigen obstakels mee.

\section{REGIO EN FACULTEIT}

Det brengt mij tot de verhouding wan deze faculteit en de regio. Meer dan bijenig andere, is de regiofunctie van deze faculteit benadrukt $(30)$. Toch is die relatie naar de eerstelijn, niet zo bloeiend als voorzien. Het terrein, de regio, blijkt niet op een simpele wijze beschikbaar. De betrekkelijke eenvoud waarmee in een laboratorium en in een kliniek door hun institutionele karater allerlei variabeler zijn te controleren, ontbreekt in de erstelijns altuatie. Noch over de hulpverleners, of $z i j$ nu onderwijs geven of onderzoek verrichten, noch over de patienten kan zomaar worden beschikt. Het is goed te beseffen, dat elke medewerking vanuit het veld" geschiedt op basis van individualiteit, vrijwilligheid en wederkerigheid. voor beide partijen, veld en universiteit, mot de verhouding aantrekkelijk en woordelig zijn!

Een van de modellen om de relatie tussen faculteit en 
eerstelijns veld vorn te geven is de zogenamde academisering (31, 32). Dat betekent het angaan van een formele, langdurige binding van praktijken en faculteit, met het doel an de hand van werkplannen, wetenschappelijk onderwijs en wetenschappelijk onderzoek in de eerstelijn mogelijk te maken en te ontwikkelen. Het woord affiliatie is een betere weergave van de relatie. Tot nu toe is die binding, op een enkele uitzondering nas helas beperkt gebleven tot huisartsen en huisartspraktijken. Ook de andere eerstelijns disciplines - en de ambulante geestelijke gezondheidszorg - behoren witdrukkelijk deel te nemen an die academisering, zoals aanvankelijk ook bedoeld (33).

Dat streven naar formalisering vordert langzaam, en niet zonder aanzienlijke weerstanden en problemen. Het zou te ver voeren om in dit kader een volledige analyse te geven. Maar vanuit mijn eigen erwaringen hier, en vanuit mijn werkplek in een "geacademiseerd" gezondheidscentrum, meen ik tenminste drie belemmerende factoren waar te nemen.

De eerste betreft de veelal tegengestelde belangen tussen faculteit en veld. De faculteit wil. krachtens haar opdracht, wetenschappelijk onderzoek doen en wetenschappelijk onderwijs geven. Daar hebben de studenten recht $O p$. De werkers in het veld willen krachtens een even honorabele opdracht, goede gezondheidszorg bieden. Daar hebben de patienten recht op. Deze onderscheiden belangen zijn in een academisch ziekenhuis wellicht hog compatibel vanwege een grotere afhankelijkheid van de patient en een al langer bestaande onderwijs en onderzoek traditie. In de eerstelijn is dat niet zo. De aard van de gepresenteerde problematiek i er miet naar. De inrichting van de lokatie is er niet naar. En de arts-patient relatie is er niet naar. En toch kunnen beide partijen niet zonder lkar. Goede gezondheidszorg is alleen mogelijk door goed opgeleide artsen en op basis van goed wetenschappelijk onderzoek. En daar is het veld voor nodig. Bovendien worden ideeten voor onderzoek en onderwijs juist valk opgedaan in de 
direkte zorg voor patienten.

Een tweede belemmerende factor is, naar mijn mening, de bestande scheiding tussen onderwijs en onderzoek. opvallend is dat met ruim de helft van de huisartspraktijken in Limburg in de 1000 der jaren, wat betreft onderwija" een harmonieuze samenwerking is opgebouwd, terwijl de verbreding nar onderzoek een tempo achter Iigt.

Elders in dit lands en daarmee bedoel ik het Nijmeegs Universitair Huisartsen Instituut, is echter aangetoond, dat beide stromen tot bloei komen, als er van met af aan verbindingen worden aangebracht. Ook hier kan dat gebeuren. Niet alleen onderzoek van onderwijs wordt daarmee bedoeld. Daartoe behoren ook het ontwikkelen wan standaarden door middel van consensusvorming en besliskundige analyse (34). De resultaten van dit type onderzoek dragen direkt bij aan het streven naar kaliteitsverbetering van de hulpwerlener. Onderwijsontwikkeling kan niet 108 gezien worden van de ontwikkeling van kwaliteitsnormen en toetsing van het handelen van de hulpverlener.

Een derde belemmering is mijns inziens gelegen in het ontbreken van de verwevenheid van patibntenzorg en academische taken. Behalve in overeengekomen en geformaliseerde werkolannen, dient deze ook tot uiting te komen in personen die dadwerkelijk de brugfunctie tussen de praktijk van alledag en de academische taken vervullen. Voor mijzelf als huisarts-hoogleraar is het blijuen dragen van verantwoordelijkheid voor patientenzorg een voorwarde om goed te kunnen functioneren. Immers: "men mag slechts onderwijzen wat men zelf doet" $(35):$

Om dit precaire process de LAT-relatie van regio en faculteit te doen slagen, moet ook en vooral voor de werkers in het veld de samenwerking aantrekkelijk genoeg zijn. Succesvolle samenwerking berust op het principe van wederkerigheid. Dat uraagt om een systeem, om een procedure, om een nawkeurige afoteming tussen beide partijen en een nieuwe cultur binnen die verhou- 
dingen (36). Dat kost tida inspanning en geld. De contacten en contracten met de universiteit moeten inhouden, dat de professionaliteit van de hulpwerleners toeneemt en de patiuntenzorg derhalve verbetert. Dus nast onderwijs en onderzoek, voldoende aandacht voor gezondheidszorgontwikkeling, die uiteraard getwalueerd dient te worden.

En gezondheidszorg in de eersteli in betekent thuiszorg! Terreinen die wat betreft het samengan van onderzoek" onderwijs en gezondheidszorg zeer relevant zijn en warop reeds wordt gewerkt, zijn: de oudere mens en de Datibnt met kanker. Een voorbeeld om die rellevantie te illustreren: in Noord-Limburg is recent onderzoek gedaan naar de vraag naar thuiszorg door kankerpatichten in relatie tot het woorkomen van en het overlijiden aan kanker (37). Van alle overledenen aan kanker in 1982 bleek $6 t$ procent bekend te zijin bij de wijkerpleging. Bij 33 procent was de wijkverpleegkundige actief betrokken, bij 28 procent dagelijks en bij 5 procent wekelijks.

Het noodzakelijke proces van afstemming van faculteit en pegio, voorzover het de eerstelijn betreft, dient te worden ondersteund door een adequate voorziening. Die voorziening heeft drie functies: inventariseren, faciliteren en innoveren. Inventariseren van hetgeen voor partijen van belang is" op de gebieden onderwijs, onderzoek en gezondheidszorgontwikkeling. Faciliteren vam contacten over en weer, en deze beide functies zijn op hun beurt voorwardelijk voor innovatie.

Dok met de Faculteit der Gezondheidswetenschappen, denk bijvoorbeeld aan de vakgroep verplegingaingswetenschap. zullen verbindingen gellegd kunnen worder.

Natuurlijk mag een dergelijke voorziening niet interfereren met hetgeen al bestaat, zaals bijwoorbeelo het Diagnostisch Cobrdinerent Centrum. Gezocht moet worden naar dienstverlening, aanvulling en aansluiting. Inoldi dels wordt hiermee, op bescheiden schaal, begonnen. 


\section{ONDERUI ISKUND IGE CONSEQUENTIES}

Voortbouwend op het hiervoor betoogde, will ilk nu de onderwijskundige consequenties overwegen. Ik zal dat doen op geleide van de twee vragen: wat en hoe? De eerste verwijst naar inhoud, de tweede naar vorm. Het allerbelangrijkste is well dat het denken en handelen in de eerstelijn, in principe uitgat van gezondheid en gezondheidsbevordering wan personen en de rol die socialle netwerken, zoals gezinnen daarbij spelen. Het accent ligt eerder op substantide rationaliteit. Bij het denken en handelen van de intramurale zorg staan de individuele ziekten centraal. Het accent ligt eerder op functionele rationaliteit.

Kijken we naar diagnosegebonden ziekten in de eerstelijn, dan gat het vooral om gewone ziekten zoals kinderziekten, luchtweginfecties, traumata en aandoeningen van het bewegingsapparat en de huid: om psychosociale problemen: om uroege en late stadia van chronische ziekten. zoals asthmatische bronchitis, suikerziekte, hart- en vatziekten, kanker, rheuma en dergelijke (38, 39).

Kijken we naar de manier warop daarmee wordt omgegaan. dan staan diagnostiek en zorg meer op de voorgrond dan genezing. De hulpverlening bestat veeleer uit uitsluiten dan aantonen, en veeleer wit continuiteit van zorg, - veelal episodisch verleend - dan uit incidentele zorg. De persoon van de hulpyerlener wordt sterk betrokken in het proces, in de interactie met de patibnt en zijn directe omgeving. De attitude en werkwijze van de hulpverlener zijh dan ook van wezenlijke betekenis woor de kwaliteit van de relatie en daardoor voor de lkwal it eit van het huloverleningsproces.

Een eerste manier om de student deelgenoot te maken wan deze basale noties. is patibnt-gebaseerd leren. Hiermee bedoel ik dat de student, bij het vorderen van zijn studie in tomemende mate betrokken wordt bij een be- 
perkt aantal patienten. Hij volgt die patibnten een lange tijd, enige jaren. Incidenteel gebeurt het al dat een co-assistent huisartsgeneeskunde een verwezen patient vergezelt naar de polikliniek en het specilistisch consult bijwoont. Ook de omgekeerde gang is van belang. Na opname in een ziekenhuis of na onderzoek in een polikliniek, volgt de student "zijn" patitut in de eerstelijn en in zijn thulssituatie.

Men kan zich woorstellen dat zulk patient-gebonden onderwijs niet alleen platsvindt tijdens de co-assistentschappen, dus in de jaren vijf en zes, mar ook al voordien. De student zal zo op de hoogte raken van het $z$ iektebeeld van de patient, het verloop ervan, van de beleving, van de invloed van en op de thuissituatie en van de diverse hulpverleningscircuits. Met name patienten met een chronische aandoening zullen hiervoor in aanmerking komen. En die zullen er steeds meer zijn! Een toenemende integratie van theorie en praktijk kan zo in de voortgang van de studie worden bewerkstelligd. Een tweede manier die overigens zeer well kan ansluiten bij de eerste is de interprofessionele training van eerstelijns disciplines (40). De verwevenheid van sociaal-ecologische en medische factoren die het ziek zijn en de hulpverlening in de eerstelijn zo zeer kenmerken, nopen dartoe. Onderzocht zal moeten worden in hoeverre onderdelen wan de Hogere beroepsopleidingen of soortgelijke opleidingen tot wijkverpleegkundige, matschappelijk werker en fysiotherapeut kunnen aansluiten bij de huidige opleiding tot basisarts.

Dergelijke plannen kunnen niet inews en wellicht ook niet op een precies woorspelbare wijze vorm krijgen. Gedurende enige jaren zijn een reeks van experimenten nodig.

Binnenkort gat het eerste van start. Het is bedoeld voor tweedejaars studenten, die via huigartsen in geacademiseerde praktijken in contact gebracht zullen worden met een gezin. De gezinnen die darvoor in aanmerking komen zijn: gezin met een pasgeboren kind. gezin met een gehandicapt kind, gezin met een chronisch 
zieke bejaar de en dergelijke.

De leerdoelen zijn: leren zien van het gezin als aysteen, de gevolgen observeren van gezondheidsstoornissen woor het functioneren wan het gezin en de contacten en interactie met de gezondheidszorg in kart brengen. In binnen-en buttenland zijn met dergelijke stages goede ervaringen opgedaan $(41,42)$.

Als zulk een veld-stage op den duur definitief wordt, is een essentieel element toegevoegd aan het curriculum. Zo zijn ook de al jaren met succes verlopende "Orifntatie Eersteli jn" in het eerste jaar en het unieke co-assistentschap huisartsgeneeskunde in het vijfde jaar wezenlijke bestanddelen.

Nog wel minder wezenlijk, mar potentieel van groot belang zijn de stages die vanuit het skillslaboratorium worden gerealiseerd en die aansluiten bij het theoretisch curriculum.

Het zijn echter losse onderdelen, die noch inhoudeli jk, noch organisatorisch voldoende samenhang vertonen.

waar we naar toe moeten is een tranamuraal curriclum. Dat betekent enerzijds complementariteit van wat de eerste- en de tweedelijn te bieden hebben. En anderzijds het slechten van barribes tussen denken en doen. Daar kan naar toe worden gewerkt via het theoretische en het praktische deel van het curriculum. De neerslag van het theoretische deel is te vinden in de blokboeken. En die blokboeken bestaan onder andere uit casus, beschrijvingen van ziektegeschiedenissen. In slechts 60 procent beginnen die bij de huisarts, en daarvan wordt dan ook nog bijna de helft verwezen $(43)$. Op die manier wordt een volstrekt onjuiste beeldvorming teweeg gebracht. Deze wordt getypeerd door een uitspraak in Terajje, een rubriek van een bekend weekblad: "Dokter, is het ernstig of is het een eerstelijns ziekte?"

Via het praktisch medisch onderwijs kan het transmurale karakter zichtbaar worden gemakt door het al beschreven patitent-gebaseerd leren en door de invoering van thema-middagen, met name in de jaren vijf en zes, waar 
geintegreerd medisch onderwijs gestalte kan kij gen $(44)$.

Naast de vakgroep onderwijsontwikkeling en onderwijs research zijn in deze faculteit drie randwoorwarden aanwezig die de verdere uitbouw van het curriculum in de geest van de basisfilosofie en de Alma Ata declaratie in positieve zin kunnen befinvloeden (45). De eerste is het al genoemde skillsiaboratorium. Deze faculteit mag zich verheugen in het bezit van dit deelproject, dat op een systematische en ewalueerbare wijze verbindingen aanbrengt tussen theorie en prak$t i j k$, en war succesvol gepoogd wordt kennis te integremen met vaardigheden en attitude. De tweede is het academiseringsproces: warvan al eerder sprake was. Daardoor wordt het mogelijk, onder min of meer gecontroleerde condities, in een extra-murale setting op een experimentele wijze het onderwijs verder te ontwikkelen. En tenslotte makt de benoeming van een klinisch onderwijscodrdinator het mogelijk om met de kliniek als geheell te overleggen, tot onderlinge afsteming en tot een gemeenschappelijk beleid te komen.

Wat mij inspireert is niet sliechts het in onderwijskundig opzicht slechten van de muren tussen de intraw en de extramurale zorg, zelfs niet de verwezenlijking van de basisfilosofie, die ondarks alle cynisme ook hier ter stede, een grote zeggingskracht blijft houden. Neen, ten grondslag ligt de overtuiging dat de patient een betere, een volwardiger arts kan verwachten, die tegelijk rationeel werkt, zorg heeft, en zorg geeft. 
Damea en heren:

Ter afsluiting wan deze plechtige bijeenkomst, wil ik enige traditionele en persoonlijke passages uitspreken.

Hare majesteit de Konungin ben ik erkentelijk voor mijn benoeming. Ik ben een der allerlatsten die is benoend tot kroondocent.

Het College van Bestuur dank ik voor het advies hiertoe.

Ik verheug mij op de wortzetting van de plezierige en zinvolle contacten met de hoogleraren en de leden wan de wetenschappelijke staf van deze Universiteit, in het bijzonder die der Faculteit der Geneeskunde en de Faculteit der Gezondheidswetenschappen.

De visie en daadkracht van zowel de vorige dekaan. professor Greep, als van de huidige dekan, professor Sturmans, zijn zeer stimulerend voor mij geweest.

De leden van de vakgroep Huisartsgeneeskunde, wetenschappelijk en ondersteunend en beherend personeel, dank ik voor hun hartelijkheid. Laat ons gezamenlijk de hand aan de ploeg slaan. Er liggen prachtige kansen.

Met jow, Wim Brouwer, werkte ik kort maar harmoniews samen. Een deel van jouw erfgoed, reken ik tot het mi jne.

Met jou, Kees de Geus, en met jou, André Knottnerus 
hoop ik in graeiende collegialiteit te mogen doorwerken aan ons gemeenschappelijk doel: de groei en bloel van de erstelijn.

Met de collegae huisartsen en andere werkers in de eerstelijn in deze regio. verwacht ik nog lang en intensief te mogen samenwerken in een grote mate van wederkerigheid.

Met en voor de studenten wil ik mij inzetten voor voldoende mogelijkheden tot inspiratie en identificatie in de extramurale kliniek.

Van mijn vele leermeesters wil ik jou, Frans Huygen, in het bijzonder noemen. Het zal geen ingewijde vandaag $z$ ijn ontgaan dat vele van je gedachten en ideeen doorwerken. Onze gemeenschappelijke liefde voor het vak en de zorg om de toekomst ervans kenmerken onze contacten over een reeks van jaren.

Via jou memoreer ik ook de jarenlange viendschappelijke relatie met de staf van het Nijmeegs Universitair Huisartsen Instituut.

De praktijk in het Withuis te Venlo is steeds mijn voedingsbodem geweest. En wat mi betreft. zal dat nog lang zo blijwen.

Ik heb het $u$, beste patienten, niet gemakkelijk gemakt door mijn vele afwezigheden. Gelukkig makt mijn associee. Tonnie van Kessel, dit meer dan goed.

In jouw persoon, Eugene van Groeningen, will ik het bestuur van de Stichting Gezondheidscentrum withuis, dankzeggen voor de ruimte en de steun die ik steeds kreeg. Die stichting mag zich gelukkig prijzen met een 
voorzitter, die $z b$ doeltreffend visie en besturskracht combineert.

De teamleden wan het withuis, assistenten, wijkverpleegkundigen, matschappelijk werker en artsen, hebben mij steeds naat tolerantie en geborgenheid, inspiratie verschaft. Heel speciad geldt dit voor Remy en Annemie van der Grinten en Fons en Limo Receveur, die mij zoweel wriendschap en vertrouwen geven.

Mijn ouders en schoonvader mis ik. Des te verheugender is de aanwezigheid van mijn schoonmoeder, miln zuster, hijn broers en hun gel lefden.

Tenslotte, een woord van dank aan de vier vrowwen, die mij meer dan wie ook dierbaar zijn: Irma, Eva, Hendrikje en Emma.

Zonder jullie steun en toeverlaat zou ik hier niet staan.

Wat kan ik beter doen dan jouw dichtregels voorlezem, Emma die je - precies tien jaar geleden - schreef voor mijin proefschrift. 


\author{
DACHT \\ DAT HIJ DIT PAD \\ ALLEEN \\ BETRAD \\ MAAR HIJ WERKTE \\ IN HUN HANDEN \\ GREEP OH ZICH HEEN \\ EN BLEEF \\ HUILEND EN LACHEND \\ MET HEN SAMEN
}

Ik heb gezegd! 
Titeratuur.

1. Structurnota Gezondheidszorg Statsuitgeverij, 's Gravenhage, 1974.

2. Groffen W. De echelonnering van de gezondheidszorg: een denkbeeld en een misverstand.

Med Contact 1974: nr. 29: 929-32.

3. Bereidheid tot verandering.

Commissie structur en Financiering Gezondheidszorg. 's Gravenhage, 1987.

4. Kaprio LA. Primary Health Care in Europe. EURO Reports and Studies 14, world Health Organization, 1979 .

5. Urij A. Alma Ata, een mijlpal? WHO-Unicef International Conference on Primary Health care. Huisarts wet 1979: 22:77-81.

6. Wetenschappeli jke Rad voor het Regeringsbeleid. De ongel ijke verdeling van gezondheid. Staatsutgeverij, "s Gravenhage, 1987 .

7. Basisfilosofie Achtste Medische Faculteit. Med Contact 1972: nr. 33: 1-6.

8. Maessen LJG van der. Transformatie van de Gezondheidszorg in Nederland tussen 1974 en 1987, b1z. 131-4, van Gorcum, Assen/Maastrictht, 1987.

9. Bensing JM. Wie will in Nederland Primary Health Care? Med Contact 1984: nr. 5: 141-6.

10. Stevens FCJ. De bureaucratisering van het medisch specialistisch ambacht. Van Gorcum, Assen/Masatricht, 1987. 
11. Gezond Limburg 1987: $\mathrm{nr}$. 40: 7.

12. Weel $C$ van. Fysiotherapie. Huisarts wet $1987: 30: 137$.

13. Haan J de. De doktersassistente. Delegeren van taken in een huisartspraktijk. Lelystad, Meditekst III, 1986.

14. Ris BGM en Diederiks JPM. Een kritische analyse van interdisciplimaire samenwerking in de hulpverlening. T Soc Geneesk 1974: 52: 553 .

15. Wijkel D. Patientenpopulaties van huisartsen in gezondheidscentra, meermans- en solopraktijken. In: Boerma WGW en Hingstman L. De eerste lijn onderzocht. Van Loghum Slaterus, 1985.

16. Lamberts $H$. Het socialle model in de huisartsgeneeskunde: tegenover, naast, in dankzij of ondanks het medisch model. Huisarts Wet 1972 :

15: $369-83$.

17. ATIS. Mogen we even voorstellen: de vier kerndisciplines. Bunnink, 1987.

18. Philipsen H. Rationalitejt en ons oordeel over de verdwijnende patient. Gezondheid en Samenleving 1985: 6: 142-151.

19. Crebolder HFJM., Huisarts en Kinderthraiene. Med Contact 1979: nr. 47: 1496-8.

20. Smits AJA. Het huisbezoek als methode van vroegtijdige signalering. MGZ 1980: 8e jrg, 6: 20-23. 
21. Crebolder HFJM. en Louw $H$ van de. Voorwarden en normen voor het consultatiebureau in de eerste lijn. Afaraken in Limburg. Med Contact 1984: $n r .15: 467-70$.

22. Swak AJ, Kousemaker NPJ en Wilbrink-Griffioen DW. Consultatiebureaus en opvoeding. $T$ Jeugdgezondheidazorg 1987; 19: 35-7.

23. Hendriken $C$, Lund $E$ and Stumgard $E$. Coneequences of assesment and intervention among elderly people: a three vear randomised controlled trial. Br Hed I 1984: 289: 1522-4.

24. Rutten G, Eijk J van, Beek M. Controles bij dibetes mellitus. Een peilend onderzoek naar opvattingen van huisartsen en internisten. Hed Contact 1985: nr. 40:389-90.

25. Horat $F$ van der. Compliance ls vraggstuk in de arts-patient relatie. Symposium bundel Patientenwoorlichting. Masatricht, 1984.

26. Crebolder HFJM en Eijndhoven M van. De begeleiding van type-II diabeten. Huisarts Wet 1986:29 (supp 1 10): 16-9.

27. Uoorn ThB. Chronische ziekten in de huisartspraktijk. Een terreinverkenning. Utrecht, Bunge, 1983.

28. Hoe helpt de dokter. Huisurtegeneeskunde als onderdeel van de eerstelijns hulpverlening. Nederlands. Huibartsen Genootachap, 1975 .

29. Hollend naar de horizon. Huisa-tsgeneeskunde in wijkend perspectief. Nederlands Huisartsen Instituut, 1979 .

30. Brouwer Wen Romme MAG. Faculteit en eerste 
lijn. Bohn: Scheltema \& Holkema; 1981.

31. Es J van. Faculteit en eerste li in. Voorstel over de wije warop de medische faculteit kan worden betrokken bij de extramurale gezondheidszorg. Med Contact 1981: nr. 7: 179-82.

32. Browwer H. Academisering in de eerste li in noodzaak. Med Contact 1982; nr. 11: 321-2.

33. Academisering in de eerste lijn en ambulante geestelijke gezondheidszorg. Brief van de minister van Onderwijs en Wetenschappen en van de staatssecretaris van Welzin. Volksgezondheid en cultur aan de tweede Kamer, 18670, nr. 1, 1984-1985.

34. Knottnerus JA. Boumstemen vook een rationele. medische besluitvorming. Med Contact 1987: nr. $42: 501-4$.

35. Huygen FJA. Levensloop en ziekte. Afscheidscollege 1984. Katholieke Universiteit te $\mathrm{Nij-}$ megen.

36. Pollmann $T$. Niet de Nederlandse samenleving is kil en koud, alleen de Nederlandse overheid. Urij Nederland, jrg. $48,10.1,1987, b 1 z .5$.

37. Kanker in Nederland. Scenario"s over kanker 1985-2000. Bohn, Scheltema \& Holkema, 1987.

38. Lamberts H. Morbidity in general practice. Uitgeversmatschappij Huisartsenpers BV. Utrecht, 1984.

39. Hoogen HJM van der, Huygen FJA en Schellekens HJWG et al. Morbidity figures from general practice. Nijmegen: Nijmeega Universitair Huisartseninstituut, 1985 . 
40. Jones RVH. Working together - Learning together. occasional Paper 33. The Royal College of General Practitioners, 1986.

41. Jonge GA de. Medisch onderwijs in gastgezinnen. Hed Contact 1986: 41: 306-9.

42. Man in soclety. The family placement 1985-1987. General practice Unit. Department of Community Health. University of Leicester.

43. Persoonlijke mededeling $N$ L'Espoir, Vakgroep Onderwijaontwikkeling en Onderwijsresearch RL Maastricht.

44. Nota praktisch medisch Onderwijs im het vijfde en zesde jaar. Bureau Onderwijs, Faculteit der Geneeskunde, Rijksuniversiteit Limburg, 1984.

45. Walton HJ. A reorientation in medical education. Medical Education 1984: 18: 1-2. 